\title{
Molecular detection of oomycetes species in water courses
}

\author{
Tomasz Oszako $\bowtie$, Katarzyna Sikora ${ }^{2}$, Lassaâd Belbahri ${ }^{3}$, Justyna A. Nowakowska ${ }^{4}$ \\ ${ }^{1}$ Bialystok University of Technology, Faculty of Forestry in Hajnówka, Piłsudskiego 8, 17-200 Hajnówka, Poland, \\ e-mail: T.Oszako@ibles.waw.pl \\ ${ }^{2}$ Forest Research Institute, Department of Forest Protection, Sękocin Stary, Braci Leśnej 3, 05-090 Raszyn, Poland \\ ${ }^{3}$ University of Neuchâtel, Laboratory of Soil Biology, Rue Emile Argand 11, 2009 Neuchâtel, Switzerland \\ ${ }^{4}$ Forest Research Institute, Laboratory of Molecular Biology, Sękocin Stary, Braci Leśnej 3, 05-090 Raszyn, Poland
}

\section{Abstract}

In Poland, about $20 \%$ of forest nurseries use irrigation water coming from natural superficial reservoirs, presumed to be the first source of infection caused by harmful pathogens belonging to the Oomycota class, especially Phytophthora genus and Pythium genus. The forest nursery is the only place where forest managers can react before pathogens leave it with asymptomatic plants or soil attached to their roots. The aim of this research was detection and identification phytopathogens in water samples. In order to recognise genus Phytophthora or Pythium in water collected from 33 places in five different forest districts in Poland, two DNA-based approaches of identification were applied: (i) the TaqMan probes, and (ii) sequencing of the ITS6/4 region.

The genomic DNA was obtained from 17 of 33 investigated water samples. TaqMan probes helped to identify 8 oomycetes present in 17 water samples. Based on ITS rDNA sequencing data, pathogens were identified in 17 cases, and this to the genus level (6 cases) and to the species level (11 cases). In total five Oomycetes species were identified, i.e. 3 Pythium species (Py. citrinum, Py. angustatum, Py. helicoides) and two Phytophthora species (P. lacustris sp. nov. - former taxon Salixsoil, P. gallica sp. nov.).

\section{KeY WORDS}

ITS, forest nurseries, Phytophthora, Pythium, sequencing, TaqMan probes, water courses

\section{INTRODUCTION}

Many forest nurseries (ca. 20\%) in Poland take water from superficial sources like rivers or lakes. Such water is contaminated with plant pathogens, especially those with biological cycle related to water-like oomycetes. The most harmful organisms belong to Phytophthora and Pythium genus. Their occurrence in water was already identified by horticulturists (Orlikowski 2006;
Orlikowski et al. 2007, 2009). In this paper, we wanted to check whether pathogenic oomycetes are present in small streams passing through forests and fields in eastern part of Poland. To this aim, two approaches were adopted: (i) TaqMan probes were applied in order to recognise genus Phytophtora and/or Phytium, and (ii) sequencing of the ITS4/6 region helped to identify oomycetes to the species level. 


\section{Methodology}

Water samples (Tab. 1, Fig. 1) of 1.51 volume each were filtered through several membrane filters in order to collect mycelium and spores of oomycetes presumably present in streams. In the first round, water was filtered through $8 \mu \mathrm{m}$ diameter pores filter; filters were then collected and kept at $4^{\circ} \mathrm{C}$ until further processing. In the second round, water was filtered through $5 \mu \mathrm{m}$ in diameter pores filter; collected filters were handled as described above.

Table 1. Characteristics of sites where water samplings were preformed

\begin{tabular}{|c|c|c|c|}
\hline No. & $\begin{array}{c}\text { Forest } \\
\text { directorate }\end{array}$ & Water origin & Coordinates \\
\hline 1 & 2 & 3 & 4 \\
\hline 1 & Borki & Lake in nursery & $\begin{array}{l}54^{\circ} 5^{\prime} 18.02^{\prime \prime} \mathrm{N}, \\
21^{\circ} 54^{\prime} 41.18^{\prime \prime} \mathrm{E}\end{array}$ \\
\hline 2 & Borki & Litygajno lake & $\begin{array}{l}54^{\circ} 66^{\prime} 5.02 ” \mathrm{~N}, \\
22^{\circ} 99^{\prime} 43.63 ” \mathrm{E}\end{array}$ \\
\hline 3 & Borki & Lake in nursery & $\begin{array}{l}54^{\circ} 5^{\prime} 18.02^{\prime \prime} \mathrm{N}, \\
21^{\circ} 54^{\prime} 41.18^{\prime \prime} \mathrm{E}\end{array}$ \\
\hline 4 & Borki & Lake in nursery & $\begin{array}{l}54^{\circ} 5 ' 18.02^{\prime \prime} \mathrm{N} \\
21^{\circ} 54^{\prime} 41.18^{\prime \prime} \mathrm{E}\end{array}$ \\
\hline 5 & Borki & Litygajno lake & $\begin{array}{l}54^{\circ} 66^{\prime} 5.02 ” \mathrm{~N}, \\
22^{\circ} 99^{\prime} 43.63 ” \mathrm{E}\end{array}$ \\
\hline 6 & Borki & Wolisko lake & $\begin{array}{l}54^{\circ} 5^{\prime} 52.75^{\prime \prime} \mathrm{N}, \\
22^{\circ} 5^{\prime} 18.92^{\prime \prime} \mathrm{E}\end{array}$ \\
\hline 7 & Borki & Litygajno lake & $\begin{array}{l}54^{\circ} 66^{\prime} 5.02^{\prime \prime} \mathrm{N}, \\
22^{\circ} 99^{\prime} 43.63^{\prime \prime} \mathrm{E}\end{array}$ \\
\hline 8 & Białowieża & Narewka river & $\begin{array}{l}52^{\circ} 41 ' 43.03{ }^{\prime \prime}, \\
23^{\circ} 51 ' 47.86^{\prime \prime} \mathrm{E}\end{array}$ \\
\hline 9 & Białowieża & Leśna river & $\begin{array}{l}52^{\circ} 44^{\prime} 37.00^{\prime \prime} \mathrm{N}, \\
23^{\circ} 34^{\prime} 41.00^{\prime \prime} \mathrm{E}\end{array}$ \\
\hline 10 & Hajnówka & Orlanka river & $\begin{array}{l}52^{\circ} 44^{\prime} 46^{\prime \prime} \mathrm{N}, \\
23^{\circ} 19^{\prime} 33^{\prime \prime} \mathrm{E}\end{array}$ \\
\hline 11 & Białowieża & Krynica river & $\begin{array}{l}52^{\circ} 44^{\prime} 8.15^{\prime \prime} \mathrm{N}, \\
23^{\circ} 45^{\prime} 50.144^{\prime} \mathrm{E}\end{array}$ \\
\hline 12 & Rudka & Forest stream & $\begin{array}{l}52^{\circ} 44^{\prime} 25.00^{\prime \prime} \mathrm{N}, \\
22^{\circ} 52^{\prime} 54.00^{\prime \prime} \mathrm{E}\end{array}$ \\
\hline 13 & Rudka & Forest stream & $\begin{array}{l}52^{\circ} 44^{\prime} 14.42 ” \mathrm{~N}, \\
22^{\circ} 51^{\prime} 57.59 ’ \mathrm{E}\end{array}$ \\
\hline 14 & Borki & Wolisko lake & $\begin{array}{l}54^{\circ} 5^{\prime} 52.75^{\prime \prime} \mathrm{N}, \\
22^{\circ} 5^{\prime} 18.92^{\prime \prime} \mathrm{E}\end{array}$ \\
\hline 15 & Żednia & Lake Siemianówka & $\begin{array}{l}52^{\circ} 54 ' 17.22^{\prime \prime} \mathrm{N}, \\
23^{\circ} 50 \text { '8.54’'E }\end{array}$ \\
\hline
\end{tabular}

\begin{tabular}{|c|c|c|c|}
\hline 1 & 2 & 3 & 4 \\
\hline 16 & Rudka & Nurzec river & $\begin{array}{l}52^{\circ} 44^{\prime} 20.00^{\prime \prime} \mathrm{N}, \\
22^{\circ} 49^{\prime} 47.00^{\prime \prime} \mathrm{E}\end{array}$ \\
\hline 17 & Białowieża & Narewka river & $\begin{array}{l}52^{\circ} 41^{\prime} 24.67^{\prime \prime} \mathrm{N}, \\
23^{\circ} 52^{\prime} 44.61^{\prime \prime} \mathrm{E}\end{array}$ \\
\hline 18 & Borki & Wolisko lake & $\begin{array}{l}54^{\circ} 5,52.75^{\prime \prime} \mathrm{N}, \\
22^{\circ} 5^{\prime} 18.92^{\prime \prime} \mathrm{E}\end{array}$ \\
\hline 19 & Rudka & Nurzec river & $\begin{array}{l}52^{\circ} 44^{\prime} 211^{\prime \prime} \mathrm{N}, \\
22^{\circ} 49^{\prime} 48^{\prime \prime} \mathrm{E}\end{array}$ \\
\hline 20 & $\begin{array}{l}\text { Bielsk } \\
\text { Podlaski }\end{array}$ & Biała river & $\begin{array}{l}52^{\circ} 45^{\prime} 42.00^{\prime \prime} \mathrm{N}, \\
23^{\circ} 11^{\prime} 37.00^{\prime} \mathrm{E}\end{array}$ \\
\hline 21 & Rudka & Forest stream Brok & $\begin{array}{l}52^{\circ} 42^{\prime} 10.00^{\prime \prime} \mathrm{N}, \\
21^{\circ} 54^{\prime} 21.00^{\prime \prime} \mathrm{E}\end{array}$ \\
\hline 22 & Rudka & Forest stream Turka & $\begin{array}{l}52^{\circ} 42^{\prime} 1.00^{\prime} \mathrm{N} \\
21^{\circ} 52^{\prime} 20.00^{\prime \prime} \mathrm{E}\end{array}$ \\
\hline 23 & Rudka & $\begin{array}{l}\text { Forest stream } \\
\text { Truchełka }\end{array}$ & $\begin{array}{l}52^{\circ} 41^{\prime} 24.00 ” \mathrm{~N}, \\
21^{\circ} 42^{\prime} 5.00^{\prime} \mathrm{E}\end{array}$ \\
\hline 24 & Przasnysz & Forest nursery & $\begin{array}{l}53^{\circ} 1 ' 29.42^{\prime \prime}, \\
20^{\circ} 52^{\prime} 49.56^{\prime} \mathrm{E}\end{array}$ \\
\hline 25 & Przasnysz & Forest nursery & $\begin{array}{l}53^{\circ} 1 ' 29.42^{\prime \prime} \mathrm{N}, \\
20^{\circ} 52^{\prime} 49.56^{\prime} \mathrm{E}\end{array}$ \\
\hline 26 & Koło & Forest nursery & $\begin{array}{l}52^{\circ} 19^{\prime} 46.19^{\prime \prime} \mathrm{N}, \\
18^{\circ} 45^{\prime} 0.31^{\prime \prime} \mathrm{E}\end{array}$ \\
\hline 27 & Koło & Forest nursery & $\begin{array}{l}52^{\circ} 19^{\prime} 46.19^{\prime \prime} \mathrm{N}, \\
18^{\circ} 45^{\prime} 0.31^{\prime \prime} \mathrm{E}\end{array}$ \\
\hline 28 & Koło & Forest nursery & $\begin{array}{l}52^{\circ} 19^{\prime} 46.19^{\prime \prime} \mathrm{N}, \\
18^{\circ} 45^{\prime} 0.31^{\prime \prime} \mathrm{E}\end{array}$ \\
\hline 29 & Koło & Forest nursery & $\begin{array}{l}52^{\circ} 19^{\prime} 46.19^{\prime \prime} \mathrm{N}, \\
18^{\circ} 45^{\prime} 0.31^{\prime \prime} \mathrm{E}\end{array}$ \\
\hline 30 & Koło & Forest nursery & $\begin{array}{l}52^{\circ} 19^{\prime} 46.19^{\prime \prime} \mathrm{N}, \\
18^{\circ} 45^{\prime} 0.31^{\prime \prime} \mathrm{E}\end{array}$ \\
\hline 31 & Białowieża & Narewka river & $\begin{array}{l}52^{\circ} 42^{\prime} 5.19{ }^{\prime} \mathrm{N}, \\
23^{\circ} 51^{\prime} 1.56^{\prime} \mathrm{E}\end{array}$ \\
\hline 32 & Białowieża & $\begin{array}{l}\text { Lake in Białowieża } \\
\text { park }\end{array}$ & $\begin{array}{l}52^{\circ} 42^{\prime} 6.35^{\prime \prime}, \\
23^{\circ} 50 ' 45.03^{\prime} \mathrm{E}\end{array}$ \\
\hline 33 & Białowieża & $\begin{array}{l}\text { Teremiski- Białowieża, } \\
\text { Narewka river }\end{array}$ & $\begin{array}{l}52^{\circ} 42^{\prime} 21.21^{\prime \prime} \mathrm{N}, \\
23^{\circ} 49^{\prime} 35.98^{\prime \prime} \mathrm{E}\end{array}$ \\
\hline
\end{tabular}

In order to obtain pure cultures of investigated water oomycetes, filter discs $(5 \mu \mathrm{m})$ were placed on selective medium PARPNH (unclarified V8-agar amended with $10 \mu \mathrm{g} \mathrm{ml}^{-1}$ pimaricin, $200 \mu \mathrm{g} \mathrm{ml}^{-1}$ ampicillin, $10 \mu \mathrm{g} \mathrm{ml}^{-1}$ rifampicin, $25 \mu \mathrm{g} \mathrm{ml}^{-1}$ pentachloronitrobenzene (PCNB), $50 \mu \mathrm{g} \mathrm{ml}^{-1}$ nystatin, and $50 \mu \mathrm{g} \mathrm{ml}^{-1}$ hymexazol) and left for $24 \mathrm{~h}$ at $22^{\circ} \mathrm{C}$. After $24 \mathrm{~h}$, fil- 
ter discs were removed, and plates with medium were incubated for next 5 days. Every day, plates were investigated, and pure isolates were subcultured on fresh PARPNH medium. Further cultivation of pure cultures was done on $\mathrm{V} 8$ agar medium at $22^{\circ} \mathrm{C}$.

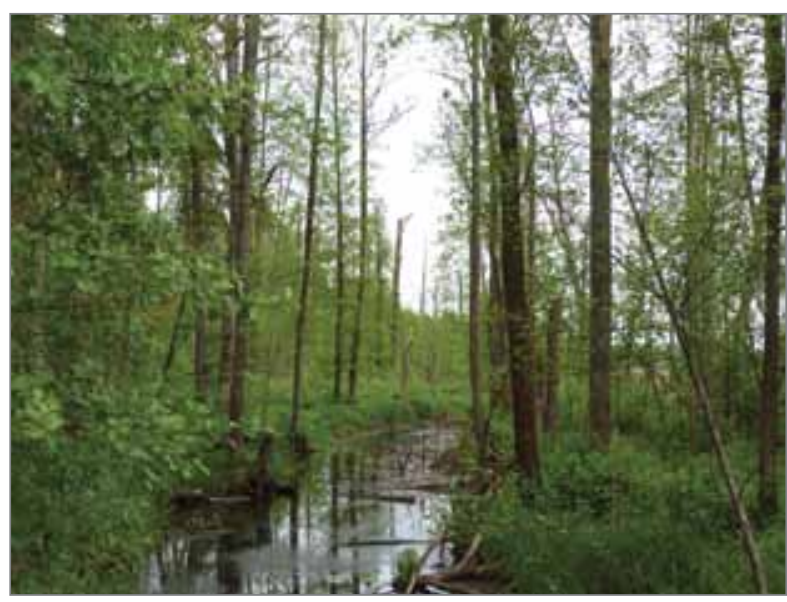

Figure 1. Alder decline along Krynica river in Białowieża forest district

Pure cultures, resistant to selective antibiotics present in medium, were obtained from samples: 10,11 , $12,13,19,22,23,28,29,30$, and subjected to further molecular analyses.

\section{DNA EXTRACTION}

Prior to DNA extraction, pure cultures of isolated organisms were cultivated in V8 liquid medium for 5 days at $22^{\circ} \mathrm{C}$. Mycelium was ground with mortar and pestle in the presence of liquid nitrogen, and nucleic acids extraction was performed using Qiagen kit according to the manufacturer's instructions (QIAGEN, Warsaw, Poland). Quality and quantity of extracted DNA were analysed through agarose gel electrophoresis and with NanoDrop ${ }^{\circledR}$ ND-1000 (Wilmington, USA).

\section{TAQMan PCR}

TaqMan PCR amplification of the internal transcribed spacer 1 (ITS-1) regions of selected Oomycetes isolates was performed with FITS_15Ph; RITS_279Ph primers and so called All_Phytophthora probe as described by Kox et al. (Tab. 2). Amplification of gDNAs was followed by Chromo4 Real Time PCR System (BioRad) and the $\mathrm{iQ}{ }^{\circledR}$ Supermix (Biorad). Reaction mixture of $30 \mu 1$ contained $15 \mu \mathrm{l}$ of $2 \mathrm{x}, 0.6 \mu \mathrm{l}$ of $50 \mathrm{x}$ ROX Reference Dye II, $83 \mathrm{nM}$ TaqMan probe, $250 \mathrm{nM}$ of each primers and $2 \mu \mathrm{l}$ of genomic DNA (in concentration $1 \mathrm{ng} / \mu \mathrm{l})$. The results of TaqMan PCR (Ct value) are described in Table 3.

Table 2. Sequences of oligonucleotides used in the study

\begin{tabular}{|l|c|c|}
\hline \multicolumn{1}{|c|}{ Name } & Sequence (5'-3') & Modifications \\
\hline FITS_15Ph & $\begin{array}{r}\text { TGCGGAAAGGATCAT- } \\
\text { TACCACACC }\end{array}$ & - \\
\hline RITS_279Ph & $\begin{array}{r}\text { GCGAGCCTAGACATC- } \\
\text { CACTG }\end{array}$ & - \\
\hline $\begin{array}{l}\text { All_Phytoph- } \\
\text { thora probe }\end{array}$ & $\begin{array}{r}\text { TTGCTATCTAGTTA- } \\
\text { AAAGCA }\end{array}$ & FAM/MGB \\
\hline ITS6 & $\begin{array}{r}\text { AAGGTGAGTCGTAA- } \\
\text { CAAGG }\end{array}$ & \\
\hline ITS4 & $\begin{array}{r}\text { TCCTCCGCTTATT- } \\
\text { GATATGC }\end{array}$ & \\
\hline
\end{tabular}

Table 3. Results on TaqMan PCR amplification of ITS1 region of rDNA

\begin{tabular}{|c|c|c|c|}
\hline Sample & Position & Dye & Ct value \\
\hline $10 / 1$ & A7 & FAM & 18.97 \\
\hline $10 / 2$ & B7 & FAM & 17.94 \\
\hline 11 & C7 & FAM & 18.11 \\
\hline $12 / 1$ & D7 & FAM & N/A \\
\hline $12 / 2$ & E7 & FAM & N/A \\
\hline $13 / 1$ & F7 & FAM & N/A \\
\hline $13 / 2$ & G7 & FAM & 16.90 \\
\hline $19 / 1$ & H7 & FAM & 18.06 \\
\hline $19 / 2$ & A8 & FAM & 23.31 \\
\hline $22 / 1$ & B8 & FAM & N/A \\
\hline $22 / 2$ & C8 & FAM & N/A \\
\hline 23 & D8 & FAM & 23.89 \\
\hline $28 / 1$ & E8 & FAM & N/A \\
\hline $28 / 2$ & F8 & FAM & 21.37 \\
\hline $29 / 1$ & G8 & FAM & N/A \\
\hline $29 / 2$ & H8 & FAM & N/A \\
\hline 30 & A9 & FAM & N/A \\
\hline
\end{tabular}




\section{DNA SEQUENCING AND OOMYCETE SPECIES IDENTIFICATION}

rDNA region (ITS1-5,8SrRNA-ITS2) of all DNA samples, regardless of TaqMan PCR results, were sequenced using primers ITS6/ITS4 as described by White et al. (1990) and Cooke et al. (2000). Sequencing was performed in $\mathrm{CEQ}^{\mathrm{TM}} 8000$ sequencer (Beckman Coulter Inc., Fullerton, USA) and data analysis performed with BioEdit software v 7.1.3 (http://www.mbio.ncsu.edu/ Bioedit/bioedit.html). Consensus sequence was compared with sequences deposited in GenBank (http://www. ncbi.nlm.nih.gov) and the species was identified based on $100 \%$ similarity at the nucleotide level. Phylogram of sequences obtained from analysed DNA samples was built with MEGA 6 software (Tamura et al. 2013).

\section{Results AND DISCUSSION}

Analysis of DNA extracted from pure cultures with TaqMan PCR, revealed that 8 of total 17 sequenced samples were recognized by Phytophthora-specific probe (Tab. 3). Even though mycelium growth was observed on selective medium in rest of the samples, they were not recognised as Phytophthora by the TaqMan probe.

Based on sequencing data, three Pythium and two Phytophthora species were identified in the investigated water samples (Tab. 4). Phytophthora lacustris sp. nov. (former taxon Salixsoil) is considered to be typical organism existing natural water ecosystems (Nechwatal et al. 2013). Phytophthora gallica sp. nov. was isolated from rhizosphere soil of a declining oak in Northeast France, and from the rhizosphere of Phragmites australis in south-west Germany in 1998 and 2004 (Jung and Nechwatal 2008). It is first report of this species in Poland. Pythium citrinum is closely related to Py. sterilum sp. nov., which was 10 years ago already found in Poland (Belbahri et al. 2006). To our knowledge, there were no records about the presence of Py. citrinum in Polish ecosystems, so far. Pythium angustatum n. sp. has been reported as parasitic in green algae (Sparrow 1931). The last mentioned Pythium species found in water courses, and Pythium helicoides causes root rot of miniature roses (Kageyama et al. 2002).

Tentative identification to species level of oomycetes in other water samples failed.
In four cases of oomycetes identification, there were no concordance between two molecular methods used (Tab. 4). The mentioned cases concerned Py. citrinum and Py. sterilum. Since Phytophthora and Pythium genus are closely related in taxonomy, a high similarity in ITS sequences, especially in regions close to $18 \mathrm{~S}$ and 5.8S rRNA gene, was observed (Fig. 2). Therefore, some of the Pythium species may be improperly recognised by TaqMan probe. Sequencing of the DNA from all isolates, regardless the TaqMan PCR result, revealed that $P y$. citrinum and Py. sterilum are recognised by TaqMan probe (Kox et al. 2007).

Table 4. Oomycetes species identified on ITS-based sequences recognized with $100 \%$ of similarity with NCBI database

\begin{tabular}{|c|c|c|c|}
\hline $\begin{array}{l}\text { Sample } \\
\text { number }\end{array}$ & Species & $\begin{array}{c}\text { Accession } \\
\text { number to } \\
\text { NCBI }\end{array}$ & $\begin{array}{c}\text { Concordance } \\
\text { with TaqMan } \\
\text { detection }\end{array}$ \\
\hline $10 / 1$ & Phytophthora lacustris & JX271790 & + \\
\hline $10 / 2$ & Phytophthora lacustris & JX271791 & + \\
\hline 11 & Pythium citrinum & JX271792 & - \\
\hline $12 / 1$ & Pythium sp. & JX271793 & + \\
\hline $12 / 2$ & Pythium angustatum & JX271794 & + \\
\hline $13 / 1$ & Pythium sp. & JX271795 & + \\
\hline $13 / 2$ & Phytophthora lacustris & JX271796 & + \\
\hline $19 / 1$ & Pythium sterilum & JX271797 & - \\
\hline $19 / 2$ & Pythium sterilum & JX271798 & - \\
\hline $22 / 1$ & Pythium angustatum & JX271799 & + \\
\hline $22 / 2$ & Pythium sp. & JX271800 & + \\
\hline 23 & Pythium sterilum & JX271801 & - \\
\hline $28 / 1$ & Pythium helicoides & JX271802 & + \\
\hline $28 / 2$ & Phytophthora gallica & JX271803 & + \\
\hline $29 / 1$ & Pythium sp. & JX271804 & + \\
\hline $29 / 2$ & Pythium sp. & JX271805 & + \\
\hline 30 & Pythium sp. & JX271806 & + \\
\hline
\end{tabular}

The occurrence of plant pathogens in water courses (especially plant destroyers as phytophthoras) is an important information for nursery managers responsible for the health of plants for plantings. In Poland, about $20 \%$ of forest nurseries use irrigation water coming from natural superficial reservoirs. The only filters 
they use (sand filters working under high pressure of water) are not able to stop all microscopic organism quickly passing through the sand particles, including plant pathogens. The filtration process is quite efficient in purifying water from weed seeds but not from propagules of Phytophthora and Pythium species, which are often found in water (also in investigated samples). Orlikowski et al. (2008) found Phytophthora species in rivers and confirmed pathogenicity of $P$. citricola toward alder, rhododendron and thuja (now $P$. plurivora, Jung and Burgess 2009). Apart from P. plurivora, he also listed P. cambivora, $P$. citrophthora and P. cryptogea, as well as two quarantine species: $P$. cinnamomi and $P$. ramorum. The last one is not only a cause of Sudden Oak Death in USA but also very harmful organism of Japanese larch in Great Britain. P. cinnamomi has large number of potential hosts and is devastating forest ecosystems in Australia.

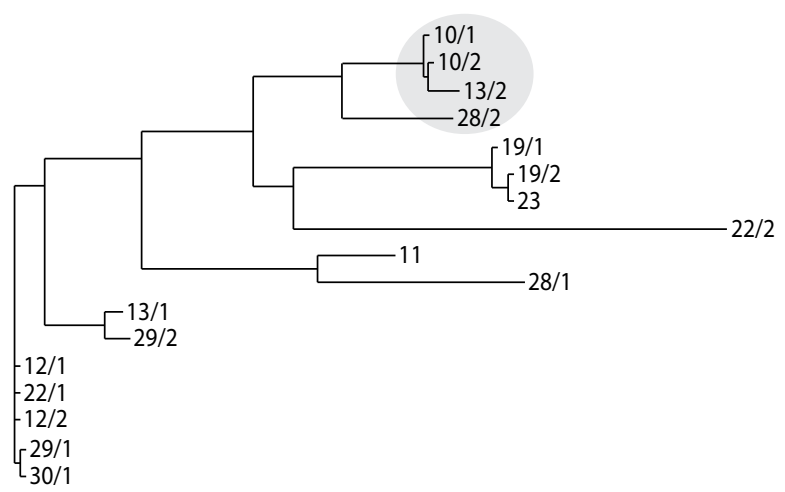

Figure 2. Phylogram of sequences obtained from analysed DNA samples. With circle a Phytophthora clade is marked

On the other hand, nursery is the only place where forest managers can react before pathogens leave it with asymptomatic plants or soil attached to their roots. Our report of quick DNA-based diagnosis is an important tool that can be supplied to end-users.

In addition, more detailed studies based on DNA analysis allow to detect and identify not only organisms present in water but also in soil or asymptomatic plant tissues. Knowing the exact pathogen species and their potential hosts forest allows managers to design preventive methods e.g. sowing of resistant or tolerant plants. Such approach allows to avoid infection and use of pesticides in nurseries. The use of so-called slow sand filters can be an another example of avoiding problems and coping with pathogens to reach their hosts. Finally, based on voluntary DNA tests, investigated nurseries can get certificate „free of pests”, which help plant producers to be more competitive on the national, European or international market.

\section{Acknowledgements}

We are grateful to IBL for supporting (Scholarship Funds 2016) to L.B. Authors thank COST Action FP1401, a global network of nurseries as early warning system against alien tree pests (global warning) for stimulating discussions during meetings.

\section{References}

Belbahri L., Calmin G., Sanchez-Hernandez E., Oszako T., Lefort F. 2006. Pythium sterilum sp. nov. isolated from Poland, Spain and France: its morphology and molecular phylogenetic position. FEMS Microbiology Letters, 255 (2), 209-214.

Cooke D.E.L., Drenth A., Duncan J.M., Wagels G., Brasier C.M. 2000. A molecular phylogeny of Phytophthora and related Oomycetes. Fungal Genetics and Biology, 30, 17-32.

Jung T., Burgess T.I. 2009. Re-evaluation of Phytophthora citricola isolates from multiple woody hosts in Europe and North America reveals a new species, Phytophthora plurivora sp. nov. Persoonia-Molecular Phylogeny and Evolution of Fungi, 22 (1), 95-110.

Jung T., Nechwatal J. 2008. Phytophthora gallica sp. nov., a new species from rhizosphere soil of declining oak and reed stands in France and Germany. Mycological Research, 112 (10), 1195-1205.

Kageyama K., Aoyagi T., Sunouchi R., Fukui H. 2002. Root rot of miniature roses caused by Pythium helicoides. Journal of General Plant Pathology, 68 (1), $15-20$.

Kox L., Heurneman I., van den Vossenberg B., van den Beld I., Bonants P., de Gruyter H. 2007. Diagnostic values and utility of immunological, morphological and molecular methods for in planta detection of Phytophthora ramorum. Phytopathology, 97, 1119-1129. 
Nechwatal J., Bakonyi J., Cacciola S.O., Cooke D.E.L., Jung T., Nagy Z.A., Vannini A., Vettraino A.M., Brasier C.M. 2013. The morphology, behaviour and molecular phylogeny of Phytophthora taxon Salixsoil and its redesignation as Phytophthora lacustris sp. nov. Plant Pathology, 62 (2), 355-369.

Orlikowski L.B. 2006. Relationship between source of water used for plant sprinkling and occurrence of Phytophthora shoot rot and tip blight in container-ornamental nurseries. Journal of Plant Protection Research, 46 (2), 163-168.

Orlikowski L.B., Ptaszek M., Trzewik A., Orlikowska T. 2008. Water as the source of Phytophthora species in rivers and their pathogenicity to some plants. Ecological Chemistry and Engineering Ser. A, 15 (9), 945-949.

Orlikowski L.B., Ptaszek M., Trzewik A., Orlikowska T. 2009. Water as the source of Phytophthora spp. pathogens for horticultural plants. Sodininkyste ir Darzinikyste, 28 (3), 145-151.

Sparrow F.K. 1931. Two new species of Pythium parasitic in green algae. Annals of Botany, 45(178), 257-277.

Orlikowski L.B., Trzewik A., Orlikowska T. 2007. Water as potential source of Phytophthora citricola. Journal of Plant Protection Research, 47 (2), 125-132.

Tamura K., Stecher G., Peterson D., Filipski A., Kumar S. 2013. MEGA6: Molecular Evolutionary Genetics Analysis Version 6.0. Molecular Biology and Evolution, 30 (12), 2725-2729.

White T.J., Bruns T., Lee S., Taylor J. 1990. Amplification and direct sequencing of fungal ribosomal RNA genes for phylogenetics. In: PCR Protocols. A Guide to Methods and Applications (eds.: M.A. Innis, D.H. Gelfand, J.J. Sninsky, T.J. White). Academic Press, Inc., San Diego, CA, 315-322. 